\title{
The botanic garden in a changing world
}

\section{H. B. RYCROFT*}

\begin{abstract}
The paper deals with the development of the National Botanic Gardens of South Africa at Kirstenbosch in the Cape. This garden made history by concentrating exclusively on the flora of its own country. A series of regional gardens have also been established to display and cultivate local floras.

Internationally there has been a growing awareness of the necessity for conservation of natural resources. We have been in the forefront in conserving our vegetation, and in creating a 'gene' bank of indigenous plants.

Large numbers of species are introduced into our gardens, where they are cultivated, studied, displayed, and their place in the flora determined. But this is only the beginning.

Plants and vegetation must be evaluated within the total concept of the biological and physical milieu.

Research, into the taxonomy and cultivation of horticulturally promising taxa is undertaken and should be intensified. Botanic gardens are people-orientated and the information on nature available must be disseminated. The next stage in the development of our botanic gardens is the development of an education section.

The time has also come to consider the development of a parallel system of regional exotic botanic gardens to complement the present indigenous gardens. Such a development would be complementary to the original concept and not in competition. The South African flora will remain the most important subject in the N.B.G., but South Africans must also have the opportunity to learn about other floras.
\end{abstract}

\section{RÉSUMÉ}

\section{LE JARDIN BOTANIQUE DANS UN MONDE CHANGEANT}

Ce document traite du développement des Jardins botaniques nationaux à Kirstenbosch dans la province du Cap. Ce jardin est connu pour s'être concentré exclusivement sur la flore de son propre pays. Une série de jardins régionaux ont aussi été établis pour exposer et cultiver les flores locales.

A l'échelon international une prise de conscience grandissante quant à la nécessité de protéger les ressources naturelles, s'est développée. Nous avons été à l'avant-garde en protégeant notre végétation et en créant une banque de 'gènes' des plantes indigènes.

Un grand nombre d'espèces sont introduites dans nos jardins, où elles sont cultivées, étudiées, exposées, et où leur place dans la flore est déterminée. Mais ceci n'st qu'un début.

Les plantes et la végétation doivent être évaluées dans le concept global d'un milieu biologique et physique.

La recherche dans la taxonomie et la culture de taxa horticoles prometteurs est enterprise et devrait être intensifiée. Les jardins botaniques sont orientés vers le public et les informations disponibles sur la nature doivent être diffusées. Le stade suivant dans le développement de nos jardins botaniques est le développement d'une section éducative.

Nous sommes aussi arrivés au moment d'envisager le développement d'un système parallèle de jardins botaniques régionaux exotiques pour compléter les jardins indigènes actuels. Un tel développement serait complémentaire au concept original et non en concurrence. La flore sud-africaine restera l'objet le plus important des Jardins botaniques nationaux; mais les Sud-Africains doivent aussi avoir l'occasion de connaître d'autres flores.

A botanic garden is a biological entity: plastic, vibrant, dynamic and alive. The layout, the form, the competition and, very important, the objectives and aims, change from time to time depending on needs, opportunities, developments in other fields and even on fashion.

A botanic garden that does not change becomes static, docile, stodgy and moribund. And today we are living in dramatic times of frequent change and development.

It is essential to keep up with modern trends in presentation, display, techniques and interpretation. At the same time, however, adequate restraint and dignity must be observed.

A great garden can, through inadequate or faulty management, run out of steam and stagnate. Injections of new thoughts, objectives and ideals must be made continuously or at least periodically to keep the organization vibrant and vigorous.

\footnotetext{
- National Botanic Gardens of South Africa, Kirstenbosch, Private Bag X7, Claremont 7735, South Africa.
}

We can ask the question then: what are the main requirements of a well-organized botanic garden today? I would say that it is a scientific, educational and cultural institution for the cultivation, display, scientific study and preservation of plants and plant species.

\section{Regional botanic gardens}

One of the most recent developments and a very significant one at that has been concern about the continued existence of rare, endangered or threatened species, many of whose future existence is in peril and which are perhaps on the brink of extinction.

It is generally accepted that the most effective method of saving such species is to maintain and preserve the complete habitat in which they grow. This is obviously not always possible. The next best approach is to attempt to cultivate them in a safe area which has the same or nearly the same habitat or environmental conditions.

The establishment of regional botanic gardens in various ecological areas of South Africa has done 
much to provide a number of localities where rare species indigenous to such localities can be grown.

The gardens which comprise the National Botanic Gardens of South Africa are:

1. Kirstenbosch Botanic Garden, Cape. This is the headquarters.

2. Karoo Botanic Garden, Worcester, Cape.

3. Harold Porter Botanic Garden, Betty's Bay, Cape.

4. O.F.S. Botanic Garden, Bloemfontein, Orange Free State.

5. Drakensberg Botanic Garden, Harrismith, Orange Free State.

6. Natal Botanic Garden, Pietermaritzburg, Natal.

7. Lowveld Botanic Garden, Nelspruit, Transvaal.

8. Transvaal Botanic Garden, Roodepoort, Transvaal (Operations have not yet commenced.)

Although the general policy to display, cultivate, study and preserve the indigenous flora is more or less the same in each garden, the gardens themselves differ tremendously from one another as far as climate, soils and all other environmental factors are concerned. In Kirstenbosch, the mother garden, the aim is to establish as many as possible of the 18000 native species of South Africa, but each of the regional gardens concentrates exclusively on the species which occur naturally in their respective areas.

I believe that it is true that Kirstenbosch has pioneered, on a world scale, the concept of developing regional botanic gardens throughout the country for the cultivation and conservation of the native flora. These ideas have been followed with interest by colleagues in many lands. At an International Conference which I attended at Kew in 1978 one of the main resolutions was that:

'This Conference agrees unanimously ... a and stresses ... how essential it is that all countries, where applicable, should have a suitable network of national regional botanic gardens to fulfil their fundamental part in the management and conservation of natural resources'.

Kirstenbosch was specifically mentioned as the originator of this concept and as being the first institution to put it into practice.

\section{Siting of garden}

Although a botanic garden is neither merely a city pleasure park nor simply a nature reserve, it should be situated in as pleasing and beautiful a locality as can be found within easy distance of a city or large town as possible, thus making it easily accessible to a large number of people. As a botanic garden is a scientific and educational institution, it is desirable that it should be near universities and schools. An attractive natural setting or surround uncluttered by buildings or other man-made structures on the horizon is a decided advantage.

Its beautiful backdrop of rugged rocky buttresses on the eastern slopes of Table Mountain contributes in no small measure in giving Kirstenbosch the reputation of being perhaps the most beautiful botanic garden in the world. Mountain streams flow over cascades and waterfalls through naturally forested areas before entering the garden itself.

The garden which was founded in 1913 is $12 \mathrm{~km}$ from the heart of Cape Town and covers an area of 528 ha of which 60 ha are under cultivation. The altitudinal range is from $100 \mathrm{~m}$ to over $1000 \mathrm{~m}$ above sea level.

When establishing a new garden it is most desirable to select a site with uneven topography, water features, interesting natural vegetation and an unbroken skyline. It is fortunate that we have been able to achieve this in Kirstenbosch and in its regional gardens. As can be expected, the Karoo Botanic Garden does not have any water features.

As far as possible, buildings are kept away from the central parts of the gardens and are located on the perimeter so as not to intrude into the garden areas. A programme for the building of a large new head office complex on the edge of the garden is soon to be commenced at Kirstenbosch. This will include administrative offices, herbarium, information centre, laboratories, store rooms and an auditorium. These will largely replace buildings which are at present in the garden and which will be completely removed.

\section{Layout}

Careful planning provides a layout which is both artistically attractive and scientifically functional. A botanic garden is frequented by people who seek knowledge and beauty and it is important that the display and presentation of the plants achieve this object. The basic principles of the layout can be taxonomic, morphological, ecological or geographical.

\section{Research}

A collection of gardens representing as far as possible the various ecosystems in a country is invaluable for research on plants and their relationships, not only between plant species, but between vegetation and environment and the dependence of plant on insect and animal, and of animal and insect on plant. In other words, plants and vegetation must be evaluated within the total concept of their biological and physical milieu.

G. J. Broekhuizen has conducted research on the biological relationships of the Orange-breasted Sunbird Anthobaphes violacea and the Cape Sugarbird Promerops cafer in the fynbos at Kirstenbosch and Wiens and Rourke have worked on the pollination role of rodents on some species of Protea.

Research is a fundamental requirement of an efficiently organized botanic garden and a herbarium is an essential part of it. The herbarium furnishes the scientific nucleus for the gardens without which the gardens could not rightly claim the title 'Botanic'; in fact, it can be said that the herbarium is the pulsating heart of the whole institution. 
In 1956 the South African Museum in Cape Town transferred its herbarium, the oldest in the country, to Kirstenbosch on permanent loan to be amalgamated with the Compton Herbarium. The total number of mounted sheets in the Compton Herbarium is now about a quarter of a million.

Each of the regional botanic gardens has its own herbarium, concentrating on the flora of the region which it represents. The first sets of all the regional gardens collections are filed in the Compton Herbarium.

Our research on the South African flora is centred in the Compton Herbarium and papers and monographs are produced from time to time. The volume of production is unfortunately lower than we would like. This is due in large measure to the present lack of space, funds and staff, a situation which I hope will be remedied when the new head office accommodation has been provided.

Taxonomic research, although very important, is certainly not the only type of research that should be carried out in a botanic garden. Many fields of investigation with a bearing on the activities of a botanic garden should be undertaken and are associated with ecology, physiology, pathology, cytology, genetics and with all aspects of horticultural science. For the reasons already given, not very much has been achieved in these fields at Kirstenbosch.

\section{Education}

A botanic garden plays a very important role in providing information to university students, school children and members of the general public. The education role may be direct and specific or it can be more indirect and subtle.

The Director of the gardens is one of the Professors of Botany at the University of Cape Town, thus maintaining the link that was formed when Harold Pearson, Professor of Botany at the University founded the gardens in 1913 and became the first Director.

Two qualified school teachers give instruction in nature study every school day of the year to classes of school children who come to the gardens for this purpose. Part of the instruction is given in the classrooms, but most of it takes place in the garden.

Honorary guides and guide-lecturers are provided for members of clubs, societies and other organized groups.

Most activities in a botanic garden are associated in some way or other with education. For example, the adequate labelling of plants has an educational function: it is telling the visitor something about the plant he is viewing. This is all part of the interpretive services rendered by a garden.

To meet the strong public demand for information, a well-balanced education programme should be maintained with the necessary staff and facilities to make it worthwhile both nationally and internationally. The education/information service should take on many forms, e.g. the plant collections should be provided with brief explanatory notices, self- guided tours and brochures, slide shows with synchronized tape commentaries, guided walks, short courses ranging from horticulture to demonstrations and programmes to involve visitors in some worthwhile project, etc.

\section{Conservation}

Much has been written about earlier times when persons were sent to collect plants from the furthest ends of the earth for botanic gardens, for growing or for scientific study. Sir Joseph Banks in England was responsible towards the end of the eighteenth century for sending collectors to all parts of the world to get plants for Kew Gardens. Wilfred Blunt in his 'In for a Penny' (1978) tells of Banks who was 'one of those who feel the irresistible urge to go to some remote, improbable, uncomfortable part of the world from where, unless they succumb to the climate or the assegai of an unsympathetic native, they ultimately return with a cornucopia of plants, seeds and herbarium specimens ... two hundred years ago there was almost everything still to be discovered.'

Today the emphasis has changed completely to the collection of local species. One of the encouraging facets of international thought in recent years has been a growing awareness of the absolute necessity for conservation of all natural resources. The National Botanic Gardens of South Africa has been in the forefront in stressing the importance of the preservation of our vegetation, on which all other life depends, and in the creation of a gene bank for all indigenous plants.

\section{Plant collecting}

It is the function of all botanic gardens to collect plants for growing in the garden and for study in the herbarium. Our accent is largely on species that are rare or threatened. Thus every known species of Encephalartos, several of which are very rare, is in our collection. Others can be mentioned, for example Serruria florida, Protea aristata, Orothamnus zeyheri, Moraea loubseri, Erica fairii. Brunia stokoei and many succulents, including Pachypodium namaquanum.

The endangered plant study group of the University of Cape Town has made a list of species which are threatened or endangered in the Western Cape. Of these we are successfully growing and cultivating no less than 280 at Kirstenbosch.

\section{Distribution}

Throughout the world, every botanic garden worthy of the name publishes an Index Seminum of seeds available for free exchange to botanic gardens or other scientific institutions. At Kirstenbosch another list is published and sent to each of the almost 8000 members of the Botanical Society of South Africa who are entitled to a quota of seeds free of charge, the quota ranging from 15 to 20 packets annually, according to class of membership.

Free seed despatched to botanic gardens and to members of the Botanical Society since 1953 
increased from 16064 packets to 40890 packets in 1974 and to 50092 in 1981.

The distribution of seed by botanic gardens is a usual practice, but this cannot be said about the distribution of flowering material. The National Botanic Gardens of South Africa is an exception. At many international congresses or exhibitions wild flowers from Kirstenbosch are despatched to provide decorative displays and named exhibits. The main objectives in doing so are to stimulate an interest in our unique flora and also to promote international goodwill. During 1981 no less than $3640 \mathrm{~kg}$ of cut flowers were sent to destinations such as the United Kingdom, Spain, Austria, West Germany, Australia, Italy, France, Japan, Hong Kong, Taiwan, Greece and Switzerland.

\section{Recording}

The keeping of proper records is a function of any scientifically managed organization. Index cards with adequate information which must be kept up to date are maintained for all collections in the gardens. They list data on source of the material, whether seeds, cuttings or whole plants with details of date, locality, description of the species in its natural environment, altitude, soil, climate type of vegetation community and so on. After the material has been obtained, the records indicate percentage germination, percentage survival, rate of growth, age and time of flowering, where planted out in the garden, any special treatment given and generally how the material responds to cultivation. In this way a total history is obtained of each plant.

\section{Job satisfaction}

The success of a garden depends very largely on the people who work in it. If they feel that they are important components of the whole institution and if they can have some share in decision-making they are likely to give loyal and dedicated service. Recently, staff members of Kirstenbosch and its associated gardens underwent an intensive course in management and organizational development organized for us by the School of Business Management of the University of Stellenbosch.

\section{Botanical Society of South Africa}

A botanic garden should not operate in isolation. It is important that in addition to its research role there should be public involvement and public participation in the activities of the garden. An organization of the 'Friends of the Botanic Garden' type is extremely useful in achieving this. It operates as the public arm of the institution and it can do much to assist in the important task of raising funds.

The Botanical Society of South Africa came into existence at the same time as the National Botanic Gardens of South Africa mainly to support the young enterprise in all its activities. The relationship between gardens and society is a very close one and the members feel that they have a participating share in the welfare of the gardens. The society has a finger on the pulse of modern developments and is able to assist the gardens to keep pace with advances in a changing world. 